\title{
Isolation and Characterization of Phosphate Solubilizing Streptomyces sp. Endemic from Sugar Beet Fields of the Beni-Mellal Region in Morocco
}

\author{
Yassine Aallam ${ }^{1}$, Driss Dhiba ${ }^{2} \mathbb{D}$, Sanâ̂ Lemriss ${ }^{3}{ }^{\mathbb{D}}$, Amal Souiri ${ }^{3} \mathbb{D}$, Fatma Karray ${ }^{4}$, Taoufik El Rasafi ${ }^{1,5}$, \\ Nezha Saïdi ${ }^{6}$, Abdelmajid Haddioui ${ }^{1}$, Saâd El Kabbaj ${ }^{3}$, Marie Joëlle Virolle ${ }^{7, *,+}$ and Hanane Hamdali ${ }^{1, *,+}$
}

Citation: Aallam, Y.; Dhiba, D.; Lemriss, S.; Souiri, A.; Karray, F.; Rasafi, T.E.; Saïdi, N.; Haddioui, A.; El Kabbaj, S.; Virolle, M.J.; et al. Isolation and Characterization of Phosphate Solubilizing Streptomyces sp. Endemic from Sugar Beet Fields of the Beni-Mellal Region in Morocco. Microorganisms 2021, 9, 914. https:// doi.org/10.3390/microorganisms905091

Academic Editors: Pedro M. Santos and Pedro Castro

Received: 7 April 2021

Accepted: 22 April 2021

Published: 24 April 2021

Publisher's Note: MDPI stays neutral with regard to jurisdictional claims in published maps and institutional affiliations.

Copyright: (c) 2021 by the authors. Licensee MDPI, Basel, Switzerland. This article is an open access article distributed under the terms and conditions of the Creative Commons Attribution (CC BY) license (https:// creativecommons.org/licenses/by/ $4.0 /)$.
1 Laboratory of Biotechnology and Valorization of Plant Genetic Resources, Faculty of Sciences and Technology, University of Sultan Moulay Slimane, P.O. 523, Beni-Mellal 23000, Morocco; yassine.aallam@gmail.com (Y.A.); elrasafi_taoufik@hotmail.com (T.E.R.); ahaddioui@yahoo.fr (A.H.)

2 International Water Research Institute, University Mohammed 6 Polytechnic (UM6P), Moulay Rachid, Ben Guerir 43150, Morocco; driss.dhiba@um6p.ma

3 Laboratory of Research and Medical Analysis of Gendarmerie Royale, Department of Biosafety PCL3, Rabat, Morocco; slemriss@lram-fgr.ma (S.L.); asouiri@lram-fgr.ma (A.S.); selkabbaj@lram-fgr.ma (S.E.K.)

4 Center of Biotechnology of Sfax (CBS), Laboratory of Environmental Bioprocesses (LBPE), Sfax BP: 1177-3018, Tunisia; karray.fatma@gmail.com

5 HTMR Laboratory, University Mohammed 6 Polytechnic (UM6P), Moulay Rachid, Ben Guerir 43150, Morocco

6 CRRA Rabat, Plant Breeding, Conservation and Valorization of Plant Genetic Resources Research Unit, B.P: 6356-Rabat Institutes, Rabat 415, Morocco; nezsaidi@yahoo.fr

7 Institute for Integrative Biology of the Cell (I2BC), Université Paris-Saclay, CEA, CNRS, 91198 Gif-sur-Yvette, France

* Correspondence: marie-joelle.virolle@i2bc.paris-saclay.fr (M.J.V.); hamdali_hanane@yahoo.fr (H.H.); Tel.: +212-523485112 (H.H.)

† Hanane Hamdali and Marie Joëlle Virolle contributed equally.

\begin{abstract}
In the course of our research, aimed at improving sugar beets phosphorus nutrition, we isolated and characterized Streptomyces sp. strains, endemic from sugar beet fields of the BeniMellal region, which are able to use natural rock phosphate (RP) and tricalcium phosphate (TCP) as sole phosphate sources. Ten Streptomyces sp. isolates yielded a comparable biomass in the presence of these two insoluble phosphate sources, indicating that they were able to extract similar amount of phosphorus $(\mathrm{P})$ from the latter for their own growth. Interestingly, five strains released soluble $\mathrm{P}$ in large excess from TCP in their culture broth whereas only two strains, BP, related to Streptomyces bellus and BYC, related to Streptomyces enissocaesilis, released a higher or similar amount of soluble P from RP than from TCP, respectively. This indicated that the rate of $\mathrm{P}$ released from these insoluble phosphate sources exceeded its consumption rate for bacterial growth and that most strains solubilized TCP more efficiently than RP. Preliminary results suggested that the solubilization process of BYC, the most efficient RP and TCP solubilizing strain, involves both acidification of the medium and excretion of siderophores. Actinomycete strains possessing such interesting RP solubilizing abilities may constitute a novel kind of fertilizers beneficial for plant nutrition and more environmentally friendly than chemical fertilizers in current use.
\end{abstract}

Keywords: insoluble phosphate; biosolubilizing; biofertilizer; Actinobacteria; sugar beet

\section{Introduction}

Phosphorus (P) is one of the 16 elements essential for plant growth [1]. Phosphate availability greatly determines growth and fitness of the plants and thus crops quality and yields [2]. In condition of P deficiency, plant root development is inhibited and this leads to a delay in plant growth [3]. Phosphorus concentration in natural soils varies from 50 to $3000 \mathrm{mg} \mathrm{kg}^{-1}$ of soil, yet only $0.1 \%$ of total phosphorus is really accessible to plants [4,5], Indeed, most phosphate is immobilized in the soil [6] either via its adsorption 
on soil particles, precipitation with various minerals ( $\mathrm{Al}, \mathrm{Fe}$ and $\mathrm{Ca}$ ) or interconversion into organic forms by soil-born micro-organisms [7]. To overcome this problem, nearly two millions tons of soluble chemical phosphate fertilizers are spread each year on agricultural fields worldwide [8]. However, still a significant fraction of these fertilizers is converted into insoluble forms [9].

The increasing awareness of environmental issues linked to agrochemical inputs stimulates the development of a sustainable agriculture and the replacement or complementation of the chemical fertilizers by other more ecological and environmentally friendly processes [10]. The direct use of natural rock phosphate in traditional agriculture in Morocco is one of such processes [11]. Morocco contains three quarters of the world's rock phosphate (RP) reserves [12]. $\mathrm{RP}$ is an hydroxyapatite $\left(\mathrm{Ca}_{10}\left(\mathrm{PO}_{4}\right)_{6} \mathrm{CaF}_{2}\right)$ not directly usable by plants [13] except in some acidic soils or in soils rich in specific micro-organisms able to convert insoluble phosphate into a form easily assimilable by plants [14]. Several reports demonstrated that these P-solubilizing microorganisms (PSM) could increase growth and crops yields of several agricultural plants including wheat [15], chickpea [16], rice and tomato [17] and can potentially be used as P-biofertilizers.

Sugar beet(Beta vulgaris L.) is the main industrial crop grown in the vast agricultural lands of the Beni-Mellal region of Morocco and constitutes 21.2\% of the national production of sugar beet [18]. Since increasing growth and yield of this economically important crop is a constant concern, we investigated the presence of PSM endemic to these specific soils.

Among these PSM, Actinobacteria, including Actinoplanes, Streptomyces and Micromonospora [7,13], are of special interest since besides their PSM abilities, they also produce bioactive secondary metabolites able to limit growth of various phytopathogens agents $[9,15,19-22]$ or molecules stimulating growth or eliciting natural plant defenses [23,24]. Exploring the richness of endemic PSM Actinobacteria in the soils specifically used for sugar beet cultivation is of interest to develop adequate new bio-fertilizer agents to stimulate sugar beet growth in the Beni-Mellal region. We thus screened for and isolated Actinomycetes endemic to these sugar beet rhizospheric soils that were able to grow and release soluble phosphate from insoluble phosphate sources in laboratory conditions. $\mathrm{Pu}-$ tative solubilization mechanisms used by these bacteria were discussed and taxonomic characterization of the most efficient solubilizing isolates was achieved.

\section{Materials and Methods}

\subsection{Location and Collection of Soil Samples}

The area of interest is located in the Beni-Mellal region of Morocco $\left(3220^{\prime} 22^{\prime \prime} \mathrm{N}\right.$, $6^{\circ} 21^{\prime} 39^{\prime \prime} \mathrm{W}$ ), that has an altitude of approximately $400 \mathrm{~m}$. This region is located in the irrigated perimeter of Beni Amir-Beni Moussa separated by the Oum er Rbia river [25] that creates two independent irrigated perimeters: Beni-Moussa and Beni-Amir (Figure 1; Table 1) of 33,000 ha and 69,500 ha, respectively [26]. This region is characterized by a semi-arid climate with an average rainfall generally below $280 \mathrm{~mm}$ [27] and an average temperature of $19^{\circ} \mathrm{C}$ [28].

Soil samples were collected in June 2017 from three different fields (Figure 1; Table 1). From each sampling point, $3 \mathrm{~cm}$ surface residues were first removed and three subsamples distant of $10 \mathrm{~m}$ from each other and in different directions were collected from 0 to $10 \mathrm{~cm}$ depth and thoroughly mixed to ensure samples homogeneity. All soil samples were then air dried, homogenized, sieved $(<2 \mathrm{~mm})$, placed in a sterile tightly closed polyethylene bag, stored at $4{ }^{\circ} \mathrm{C}$ and the soil was used for further experiments within $48 \mathrm{~h}$. 

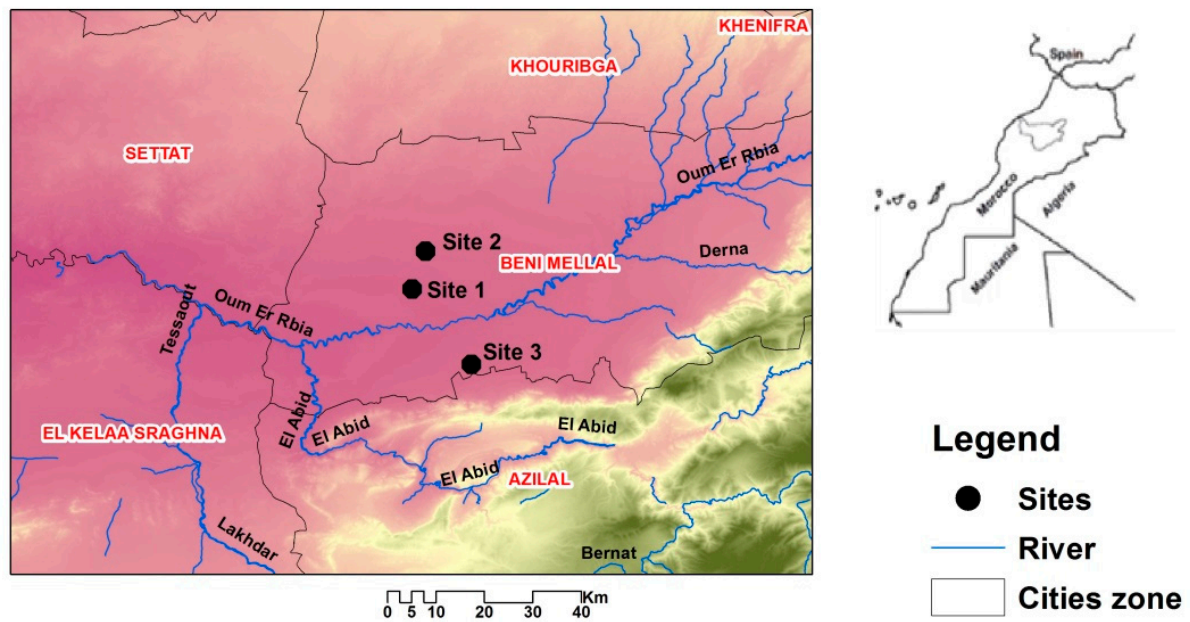

Figure 1. Map of the sampling sites of the three sugar beet agricultural soils of the Beni-Mellal region of Morocco.

Table 1. Physico-chemical characteristics of the three sugar beet soils of the Beni-Mellal region.

\begin{tabular}{|c|c|c|c|c|}
\hline Parameters & Site 1 & Site 2 & Site 3 & ANOVA \\
\hline Perimeter & \multicolumn{2}{|c|}{ Beni Amir } & Beni Moussa & \\
\hline Graphical situation & $\begin{array}{c}3240^{\prime} 10.8^{\prime \prime} \mathrm{N} \\
6^{\circ} 84^{\prime} 14^{\prime \prime} \mathrm{W}\end{array}$ & $\begin{array}{c}3247^{\prime} 34.45^{\prime \prime} \mathrm{N} \\
6^{\circ} 81^{\prime} 52.3^{\prime \prime} \mathrm{W}\end{array}$ & $\begin{array}{l}3226^{\prime} 31.29^{\prime \prime} \mathrm{N} \\
6^{\circ} 73^{\prime} 36.30^{\prime \prime} \mathrm{W}\end{array}$ & \\
\hline $\mathrm{pH}_{\text {water }}$ & $7.44 \pm 0.27^{\mathrm{a}}$ & $7.31 \pm 0.26^{\mathrm{a}}$ & $7.49 \pm 0.14^{\mathrm{a}}$ & \\
\hline $\mathrm{pH}_{\mathrm{KCL}}$ & $6.49 \pm 0.16^{\mathrm{a}}$ & $6.93 \pm 0.06^{b}$ & $7.09 \pm 0.04^{c}$ & $p<0.001$ \\
\hline Organic matter (\%) & $4 \pm 0.3^{\mathrm{a}}$ & $6 \pm 0.3^{b}$ & $4 \pm 0.2^{\mathrm{a}}$ & $p<0.001$ \\
\hline Mineral matter (\%) & $89 \pm 0.2^{a}$ & $81 \pm 0.2^{b}$ & $88 \pm 0.1^{c}$ & $p<0.001, p=0.026$ \\
\hline Water content $(\%)$ & $7.4 \pm 0.2^{\mathrm{a}}$ & $1.2 \pm 0.1^{b}$ & $7.2 \pm 0.1^{\mathrm{a}}$ & $p<0.001$ \\
\hline Electrical conductivity $(\mu \mathrm{S} / \mathrm{cm})$ & $0.40 \pm 0.13^{\mathrm{a}}$ & $0.47 \pm 0.009 \mathrm{ab}$ & $0.25 \pm 0.002{ }^{a c}$ & $p=0.015$ \\
\hline Total nitrogen $(\%)$ & $2.62 \pm 0.00^{\mathrm{a}}$ & $1.75 \pm 0.87^{\mathrm{a}}$ & $2.33 \pm 0.50^{a}$ & \\
\hline $\mathrm{P}_{2} \mathrm{O}_{5}(\%)$ & $4.96 \pm 1.22^{\mathrm{a}}$ & $5.23 \pm 1.24^{a}$ & $0.34 \pm 0.02^{b}$ & $p=0.001$ \\
\hline Magnesium oxide $\mathrm{MgO}(\%)$ & $0.95 \pm 0.16^{\mathrm{a}}$ & $1.00 \pm 0.11^{\mathrm{a}}$ & $2.22 \pm 0.28^{b}$ & $p<0.001$ \\
\hline Potassium oxide $\mathrm{K}_{2} \mathrm{O}(\%)$ & $0.25 \pm 0.03^{a}$ & $0.04 \pm 0.03^{b}$ & $0.77 \pm 0.14^{\mathrm{c}}$ & $p=0.026, p<0.001$ \\
\hline Manganese oxide MnO (\%) & $0.10 \pm 0.03^{\mathrm{a}}$ & $0.09 \pm 0.01^{\mathrm{a}}$ & $0.04 \pm 0.006^{b}$ & $p=0.009, p=0.019$ \\
\hline
\end{tabular}

Different letters indicate significant differences at $p<0.05$. LSD test was used to compare the parameter concentrations between sampling sites.

\subsection{Chemical Analysis}

Conductivity and $\mathrm{pH}$ (in water) were measured in a soil-water suspension $(1: 5 v / v)$. Potential acidity was determined after dilution of the soil sample in a suspension of potassium chloride $\mathrm{KCl} 1 \mathrm{~N}$ [29]. The organic (OM) and mineral (MM) matter were determined by ignition at $550{ }^{\circ} \mathrm{C}$ for $5 \mathrm{~h}$ in a furnace, as described in [27]. Soil moisture was assessed by measuring the evolution of the mass of $10 \mathrm{~g}$ of each sample maintained in an oven at $105{ }^{\circ} \mathrm{C}$ for $24 \mathrm{~h} \mathrm{[29].} \mathrm{The} \mathrm{Kjeldahl} \mathrm{method} \mathrm{was} \mathrm{used} \mathrm{to} \mathrm{determinate} \mathrm{the} \mathrm{total} \mathrm{concentration}$ of nitrogen. The determination of the phosphorus $\left(\mathrm{P}_{2} \mathrm{O}_{5}\right)$ content was carried out by ICPAES (Inductively coupled Plasma Atomic Emission Spectrometry, Perkin Elmer Wellesley, Waltham, MA, USA) [30]. 


\subsection{Isolation of Total Flora and of Actinomycetes}

Two grams (wet weight) of each soil sample were suspended in $18 \mathrm{~mL}$ of sterile physiological serum $(9 \mathrm{~g} / \mathrm{L}, \mathrm{NaCl})$, homogenized and sonicated as described previously [31]. Next, $0.1 \mathrm{~mL}$ of various dilutions of the treated samples was plated in triplicate on the surface of nutrient agar (Difco, Sparks, MD, USA) for Gram positive and Gram negative bacteria and of synthetic minimum medium (SMM) containing $10 \mathrm{~g} / \mathrm{L}$ glucose, $2 \mathrm{~g} / \mathrm{L}$ NaNO3, $0.5 \mathrm{~g} / \mathrm{L} \mathrm{MgSO} 4.7 \mathrm{H} 2 \mathrm{O}, 0.5 \mathrm{~g} / \mathrm{L} \mathrm{KCl}, 0.01 \mathrm{~g} / \mathrm{L}$ FeSO4.7H2O and K2HPO4 (0.5 g/L, $4.38 \mathrm{mM}$ ) as described previously [15]. The $\mathrm{pH}$ of SMM was adjusted to 7 and it was sterilized at $121^{\circ} \mathrm{C}$ for $20 \mathrm{~min}$. This medium was supplemented with $40 \mathrm{mg} \mathrm{mL} / \mathrm{L}$ actidione and $10 \mathrm{mg} / \mathrm{mL}$ nalidixic acid to inhibit growth of fungi and Gram negative bacteria, respectively. After plating, the agar plates were incubated for 21 days at $28^{\circ} \mathrm{C}$ in order to allow growth of the slow growing Actinomycetes. Actinomycetes were recognized on the basis of their morphological features described in the International Streptomyces Project (ISP) [32].

\subsection{Screening for Actinomycetes Able to Use Rock Phosphate (RP) and Tricalcium Phosphate (TCP) as Sole Phosphorus Source}

Selection of Actinomycetes able to use RP originating from Khouribga phosphate mine in Morocco [15], as sole P source, was carried out by plating 300 colonies (100 colonies from each investigated soil) on the SMM containing $0.5 \mathrm{~g} / \mathrm{L}$ of $\mathrm{RP}$ (approximately equivalent to $2.2 \mathrm{mM}$ phosphorus) as a unique P source or on the SMM containing soluble $\mathrm{K}_{2} \mathrm{HPO}_{4}$ $(0.5 \mathrm{~g} / \mathrm{L}, 4.38 \mathrm{mM})$ or no P source. Spores of Actinomycete isolates showing the most active growth on SMM containing RP as sole P source were stored in $20 \%(w / v)$ sterile glycerol at $-20^{\circ} \mathrm{C}$ and were subsequently tested for their ability to grow on SMM containing TCP $\left(0.5 \mathrm{~g} / \mathrm{L}, \mathrm{Ca}_{3}\left(\mathrm{PO}_{4}\right)_{2}\right)$ (Sigma Aldrich, Isère, France) as the sole P source.

\subsection{Quantitative Estimation of the Amount Soluble Phosphate Released in the Growth Medium by} the Selected Actinomycete Strains

The selected Actinomycete isolates were inoculated at $10^{6}$ spores $/ \mathrm{mL}$ in $250 \mathrm{~mL}$ Erlenmeyer flasks containing $50 \mathrm{~mL}$ of liquid SMM medium with $0.5 \mathrm{~g} / \mathrm{L} \mathrm{RP}$ or $0.5 \mathrm{~g} / \mathrm{L} \mathrm{TCP}$ as sole $\mathrm{P}$ source, in triplicate, and grown for 5 days at $28^{\circ} \mathrm{C}$ on a rotary shaker $(180 \mathrm{~g} / \mathrm{min})$ [15]. Every day, a $1 \mathrm{~mL}$ aliquot of each culture was taken and centrifuged at $10,000 \times g$ for $10 \mathrm{~min}$, dry biomass as well as the $\mathrm{pH}$ of the supernatant were determined. The supernatant was analyzed for $\mathrm{P}_{2} \mathrm{O}_{5}$ content by the chlorostannous reduced molybdo-phosphoric acid blue color method [33]. Similar measures were carried out in non-inoculated flasks incubated in the same conditions to determine the amount of phosphate spontaneously released from $\mathrm{RP}$ and TCP.

\subsection{Production and Detection of Siderophores: CAS Agar Plate Technique}

Siderophores production of the most efficient RP/TCP solubilizing isolates was determined using Chrome Azurol S (CAS) agar plate's method described previously [34]. Agar plugs (10 mm diameter) of Actinobacterial cultures grown on solid SMM medium containing $0.5 \mathrm{~g} / \mathrm{L} \mathrm{TCP}$ as sole P source for 5 days at $28^{\circ} \mathrm{C}$ were placed aseptically on CAS agar plate and incubated for 3 days at $30^{\circ} \mathrm{C}$. After incubation, the apparition of a yellow halo around the plugs indicated the production of siderophores [35].

\subsection{Morphological, Physiological and Chemotaxonomic Characterization of the Selected Strains}

The morphological, cultural, physiological and biochemical characteristics of the selected isolates were evaluated as described in the International Streptomyces Project [32]. Cultural characteristics were observed after growth on yeast extract-malt, extract agar (ISP2), oatmeal agar (ISP3) and inorganic salts-starch agar (ISP4) media for 7-21 days at $30{ }^{\circ} \mathrm{C}$ and the color series were determined as proposed previously [36]. The assimilation of carbohydrates was determined using the ISP9 medium containing 10 different carbohy- 
drates, as sole carbon source, at a concentration of $1 \%(w / v)$. The chemical analyses of the diaminopimelic acid isomer were performed as described previously [37].

\subsection{Amplification and Sequencing of the $16 S \mathrm{rDNA}$ of the Selected Strains}

The $10 \mathrm{TCP} / \mathrm{RP}$ solubilizing Actinobacteria isolates were grown for 2 days at $28{ }^{\circ} \mathrm{C}$ in $500 \mathrm{~mL}$ flasks containing $100 \mathrm{~mL}$ of Hickey-Tresner medium $(1 \mathrm{~g} / \mathrm{L}$ yeast extract, $1 \mathrm{~g} / \mathrm{L}$ beef extract, $2 \mathrm{~g} / \mathrm{L} \mathrm{N}-\mathrm{Z}$-Amine A (Sigma), $10 \mathrm{~g} / \mathrm{L}$ Dextrin and $20 \mathrm{mg} / \mathrm{L} \mathrm{CoCl}_{2} \cdot 6 \mathrm{H}_{2} \mathrm{O}$ ) [38], under constant agitation of $180 \mathrm{rpm}$. Biomass was harvested by centrifugation $(16,000 \times g$ for $10 \mathrm{~min}$ ) and the mycelial pellet was used for automated extraction of DNA with the Maxwell ${ }^{\circledR}$ RSC Instrument (Promega, Madison, WI, USA) and the Maxwell ${ }^{\circledR}$ RSC PureFood GMO and Authentication Kit (Promega) according to manufacturer instructions.

The $16 \mathrm{~S}$ rDNA was amplified with the PCR method using universal primers 27F (AGAGTTTGAMCCTGGCTCAG) and 1492R (GGTTACCTTGTTACGACTT). Amplification was carried out in $25 \mathrm{~mL}$ of reaction mixture containing $10 \mu \mathrm{L}$ of AccuPower Taq PCR PreMix (Bioneer, Oakland, CA, USA), $1.25 \mu \mathrm{mol}$ of each primer and $50 \mathrm{ng}$ of DNA. PCR condition was as follows: after initial denaturation $\left(96{ }^{\circ} \mathrm{C}\right.$ for $\left.1 \mathrm{~min}\right), 30$ cycles of $96{ }^{\circ} \mathrm{C}$ for $30 \mathrm{~s}, 60^{\circ} \mathrm{C}$ for $30 \mathrm{~s}$ and $72{ }^{\circ} \mathrm{C}$ for $1 \mathrm{~min} 30 \mathrm{~s}$ were performed, followed by a final extension $\left(5 \mathrm{~min}, 72^{\circ} \mathrm{C}\right.$ ). Amplification was carried out using a GeneAmp PCR 9700 System (Applied Biosystems, Foster City, CA, USA). Negative controls were included with no addition of template DNA. The amplified products were visualized on a $2 \%$ $(w / v)$ agarose gel stained with ethidium bromide. PCR products from each isolate were sequenced using $27 \mathrm{~F}$ and $1492 \mathrm{R}$ primers. Sequence similarity searches were performed against corresponding sequences of members of the Streptomycetaceae family using the online sequence analysis resources LEBIBI database [39] and GenBank through Nucleotide BLAST (http:/ / www.ncbi.nlm.nih.gov/BLAST/ accessed: 29 March 2021). Unrooted phylogenetic tree was inferred using the Neighbor-Joining method [40]. The percentage of replicate tree in which the associated taxa clustered together in the bootstrap test (1000 replicates) is shown next to the branches [41]. The evolutionary distances were computed using the Kimura 2-parameter method [42] and are expressed in number of base substitutions per site. This analysis involved 52 nucleotide sequences. Evolutionary analyses were conducted in MEGA X [43].

\subsection{Statistical Analysis}

Statistical analysis of soil chemical parameters, total flora and Actinomycete strains distribution was carried out using ANOVA, and the Duncan test was used to compare the average abundance and percentage contribution of the Actinomycete isolates to the total flora in the three studied sites. All values are means of three replicates plates from the same soil sample. Least Significant Difference (LSD) was used to compare the parameter concentrations between sampling sites and standard deviation was calculated using SPSS software 20.0 package for Windows.

\section{Results}

\subsection{Soil Analysis}

Physico-chemical proprieties of soil samples are listed in Table 1 . The tested sugar beet agricultural soils contained, on average, $5 \%$ of Organic Matter $(\mathrm{OM})$ and $86 \%$ of Mineral Matter (MM) including $2 \%$ nitrogen, $3.5 \% \mathrm{P}_{2} \mathrm{O}_{5}, 0.35 \% \mathrm{~K}_{2} \mathrm{O}, \mathrm{MgO}(1.4 \%)$ and $\mathrm{MnO}(0.08 \%)$. The $\mathrm{pH}$ of the soils was close to neutrality or slightly basic ( $\mathrm{pH} 7.4$ on average). The highest electrical conductivity indicating soil salinity was recorded in soil sample 2 with an average of $0.47(\mu \mathrm{S} / \mathrm{cm})$.

\subsection{Distribution of Total Flora and of Actinomycetes in the Sugar Beet Fields under Study}

The distribution of total flora (TF) and Actinomycetes of sugar beet soils collected from the three sites is shown in Table 2. TF was at a similar level in the three sites (on 
average $23 \times 10^{7} \mathrm{cfu} / \mathrm{g}$ of soil) (Table 2$)$. The Actinomycete isolates were significantly more abundant in sites $1(7.2 \%)$ and $3(6.73 \%)$ than in site $2(4.90 \%)$ (Table 2$)$.

Table 2. Distribution of total flora and of Actinomycete strains in the three sugar beet sites of the Beni-Mellal region.

\begin{tabular}{|c|c|c|c|c|}
\hline & Site 1 & Site 2 & Site 3 & ANOVA \\
\hline Perimeter & & & Beni Moussa & \\
\hline Total flora $\left(\times 10^{7}\right.$ UFC/g of soil $)$ & $25.66^{\mathrm{a}}$ & $25.91^{\mathrm{a}}$ & $17.08^{b}$ & \\
\hline Actinomycetes $\left(\times 10^{7}\right.$ UFC/g of soil) & $1.84^{\mathrm{a}}$ & $1.27^{\mathrm{ab}}$ & $1.15^{b}$ & $p=0.03$ \\
\hline$\%$ des Actinomycetes/Total flora & $7.2 \%$ & $4.90 \%$ & $6.73 \%$ & \\
\hline
\end{tabular}

Different letters indicate significant differences at $p<0.05$. Duncan t-test was used to compare mean percentages and Actinomycetes density.

Among the 164 Actinomycete isolates retained, 57 had the ability to grow on SMM + RP as the sole phosphate source. Among these 57 isolates, only 27 isolates $(47.36 \%)$ had also the ability to grow on SMM + TCP as unique P source. Ten of the twenty-seven isolates, showing the highest biomass yield on SMM + RP and with different morphological characteristics, were selected for further studies. Seven of these ten Actinomycete isolates were from site 1 (AI, AYD, AV, AZ, BYC, BX, and BP), one (CYM) from site 2 and two from site 3 (DE1 and DE2).

\subsection{Growth Kinetic of the Selected Actinomycete Strains in $S M M+R P$ and $S M M+T C P$}

Figure 2 clearly shows that the growth kinetics of most strains was similar in both TCP and RP. This indicated that the strains were able to assimilate similar amounts of phosphorus from these phosphate insoluble sources, with a comparable efficiency, and use it for their own growth. The only exception was the strain BP that showed a better growth on SMM + RP than on SMM + TCP. One notes that, in SMM+ TCP mainly, most strains yielded a lower biomass at day 5 than at day 4, suggesting cell lysis. However, the biomass yield was not the same for all strains and the strains could be grouped into two classes, class I with biomass yield above $70 \mu \mathrm{g} / \mathrm{mL}$ (DE2, BYC, AYD, AZ, AI and BP) and class II with biomass yield comprised between 50 and $70 \mu \mathrm{g} / \mathrm{mL}$ (AV, DE1, CYM and BX) (Figure 3). One notes that strains with the lowest biomass yields are also those yielding the lowest amount of soluble phosphate (Figure 3).

\subsection{Estimation of the Amount Soluble Phosphate Released from TCP and RP by the Selected Actinomycete Strains}

The concentration of free phosphate spontaneously released from TCP and RP in the control non-inoculated flask was 2.5 and $5 \mu \mathrm{g} / \mathrm{mL}$, respectively. The concentration of soluble phosphate in the supernatant of most strains (except perhaps CYM and BX), exceeded this value (Figure 3). This indicated that most strains were able to release phosphate from these two different insoluble phosphate sources in excess of their phosphate need to support their growth. However, the amount of soluble phosphate released greatly varied with the nature of the phosphate source and from strain to strain.

Five strains released a high $(>60 \mu \mathrm{g} / \mathrm{mL})$ and higher amount of phosphate from TCP than from RP (Figure 3), indicating that TCP was more efficiently solubilized than RP. The presence of large amounts of phosphate in the supernatant of these strains in the presence of TCP simply indicated that the rate of Pi released from TCP exceeded its rate of consumption for bacterial growth.

Strain DE2 (class I) released maximal soluble phosphate concentration $(180 \mu \mathrm{g} / \mathrm{mL})$ from TCP, whereas strains BYC (class I) and BP (class I) released maximal amounts of soluble phosphate from $\mathrm{RP}(148.05 \mu \mathrm{g} / \mathrm{mL}$ and $59.44 \mu \mathrm{g} / \mathrm{mL}$, respectively). 


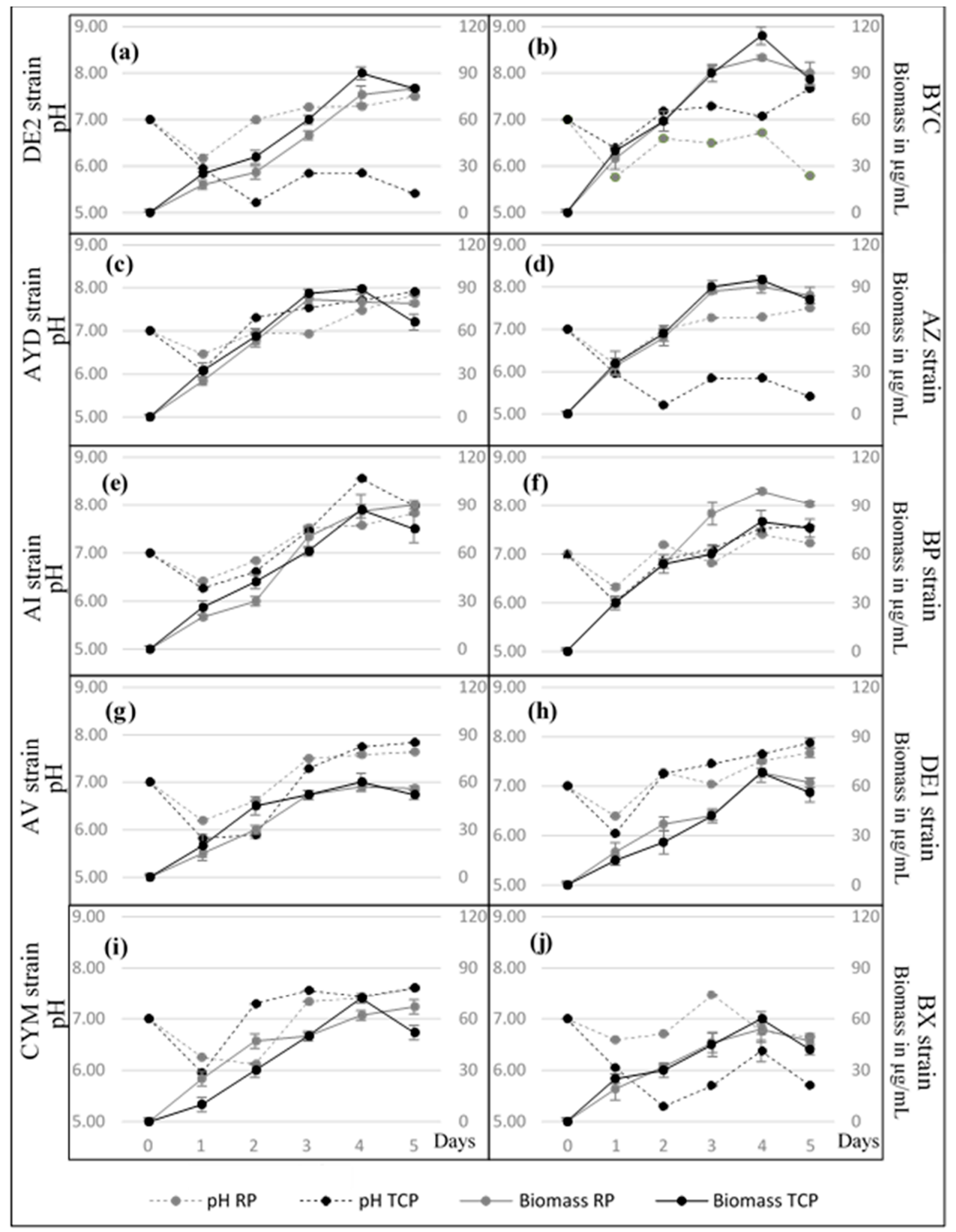

Figure 2. Evolution of the biomass (continuous lines) and the $\mathrm{pH}$ of the medium (dotted lines) of the selected Actinomycete isolates grown in SMM+ TCP (black circle) and SMM+ RP (gray circle). Error bars represent standard deviations of the mean values of the results of three independent culture replicates. 


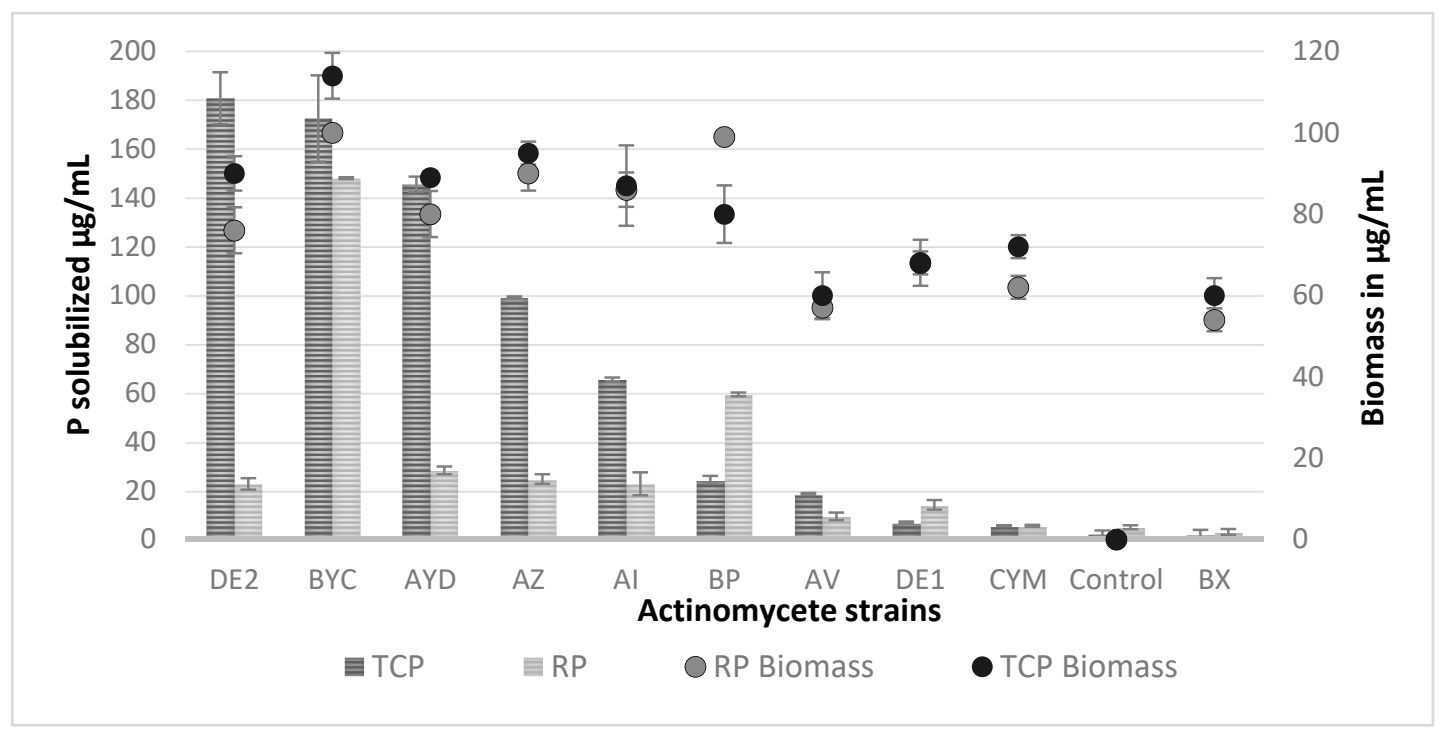

Figure 3. Concentration of soluble phosphate released $(\mu \mathrm{g} / \mathrm{mL})$ from TriCalcium Phosphate (TCP, dark gray histograms) and natural Rock Phosphate (RP, light gray histograms) in the non-inoculated flasks (control) and in the supernatant of cultures of the ten selected Actinomycete isolates grown for five days in SMM containing $0.5 \mathrm{~g} / \mathrm{L} \mathrm{RP} \mathrm{or} 0.5 \mathrm{~g} / \mathrm{L} \mathrm{TCP}$. The maximal biomass yield in $\mu \mathrm{g} / \mathrm{mL}$ of the 10 selected Actinomycete strains is shown above the histograms for TCP (black circles) and RP (gray circles). Error bars represent standard deviations of the mean values of the results of three independent culture replicates.

The strain BYC (class I) is of special interest since it was able to release a similar amount of Pi from RP $(150 \mu \mathrm{g} / \mathrm{mL})$ and TCP $(170 \mu \mathrm{g} / \mathrm{mL})$ and its biomass yield was similar with both phosphate sources (only12\% higher in SMM + RP than in SMM + TCP). The strains BP (class I) and DE1 (class II) released over 2 fold more soluble phosphate from $\mathrm{RP}(60 \mu \mathrm{g} / \mathrm{mL}$ and $15 \mu \mathrm{g} / \mathrm{mL}$, respectively) than from TCP $(25 \mu \mathrm{g} / \mathrm{mL}$ and $7 \mu \mathrm{g} / \mathrm{mL}$, respectively). The biomass yield of the strain BP was 20\% higher in SMM + RP than in SMM + TCP whereas that of the strain DE1 was similar on both P sources. Interestingly, the strains BX (class II) and CYM (class II) consumed the totality of the phosphate released. This suggested that the solubilizing ability of these strains was less efficient than that of the others.

\subsection{Cas-Agar Test and Evolution of the $\mathrm{pH}$ of the Growth Medium}

The CAS-agar test indicated that the six more efficient TCP solubilizing Actinomycete strains (DE2, AYD, BYC, AZ, AI, BP) were producing siderophores (Figure 4) as previously reported for other PSM bacteria [20,44]. However, among these strains only BYC was able to efficiently release phosphate from RP. The strains BX, AV, DE1 and CYM apparently produced little siderophores (Figure 4) and were among the strains releasing very little phosphate from TCP or RP (Figure 3). This suggested that the production of siderophores contributes to the P solubilization process.

The $\mathrm{pH}$ of the growth medium of all strains in TCP as in RP felt between 6 and 6.5 at day 1 and raised afterwards in most cases. This indicated that the earliest solubilization process might involve the excretion of organic acids. The $\mathrm{pH}$ of the medium remained below 6 for the strains DE2, AZ and BX in TCP for the following days but reached 7 or above in RP. DE2 and AZ release a fair amount of P from TCP $(180 \mu \mathrm{g} / \mathrm{mL}$ and $100 \mu \mathrm{g} / \mathrm{mL}$, respectively) but a rather weak amount from $\mathrm{RP}(20 \mu \mathrm{g} / \mathrm{mL})$ whereas $B X$ did not release any $\mathrm{P}$ from any of these phosphate sources. DE2 and AZ possibly excreted more siderophores than BX (Figure 4). 


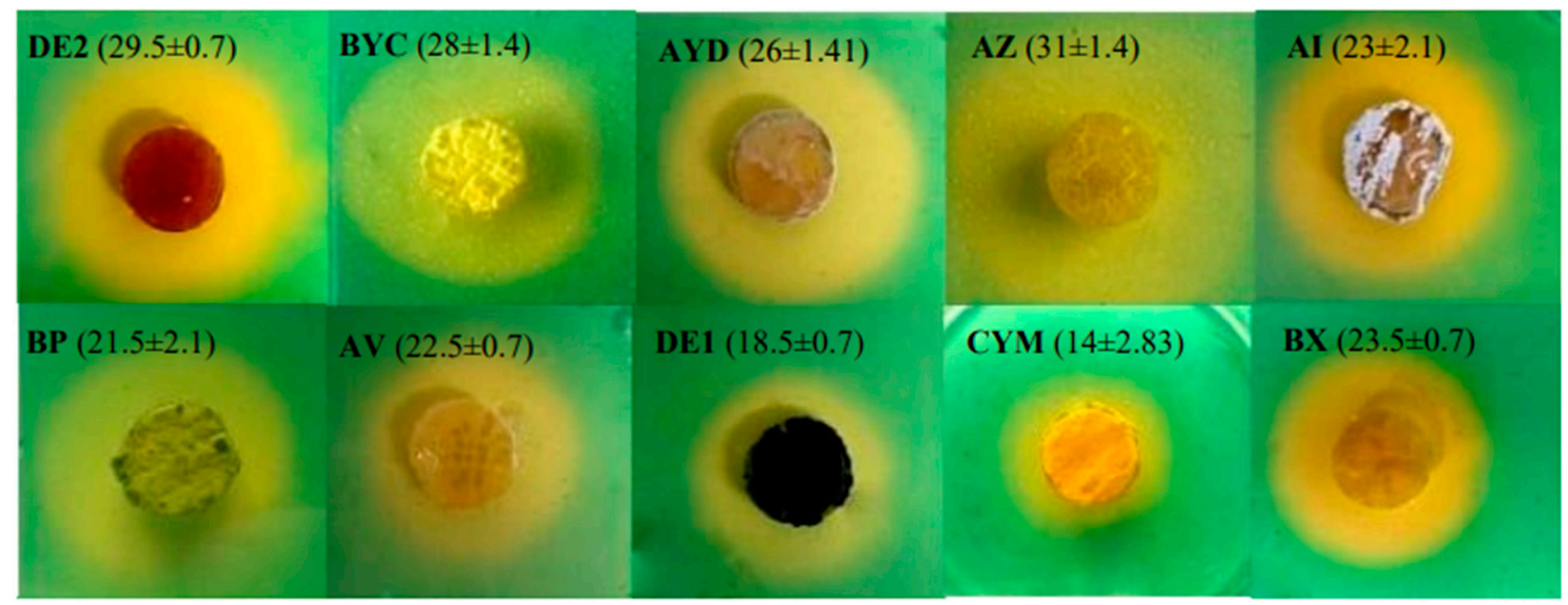

Figure 4. Halo of discoloration of CAS-agar around agar plugs of the ten most efficient TCP/RP solubilizing Actinomycete isolates originating from sugar beet soils of the Beni-Mellal region grown for five days in solid SMM containing $0.5 \mathrm{~g} / \mathrm{L} \mathrm{TCP}$ and deposited on the surface of a CAS-blue agar plate. The formation of the halo around the plugs is thought to be due to the excretion of siderophores. Diameters of the halos expressed in $\mathrm{mm}$ are shown in proximity of the name of the isolates.

In $\mathrm{RP}$, the $\mathrm{pH}$ of the medium remained above 7 for most strains except for $\mathrm{BYC}(\mathrm{pH}$ between 6.5 and 6.8 at days 2, 3 and 4) and CYM (pH 6 at days 1 and 2). BYC released a fair amount of phosphate from RP as well as from TCP $(150 \mu \mathrm{g} / \mathrm{mL}$ and $170 \mu \mathrm{g} / \mathrm{mL}$, respectively) whereas CYM hardly released any $\mathrm{P}$ from these two phosphate sources. BYC, but not CYM, was shown to excrete siderophores (Figure 4).

The $\mathrm{pH}$ of the medium of the 5 remaining strains (AYD, BP, AV, DE1 and $\mathrm{AI}$ ) was rather similar in TCP and RP and above 7. AYD and AI, produced siderophores and released a fair amount of phosphate from TCP $(140 \mu \mathrm{g} / \mathrm{mL}$ and $60 \mu \mathrm{g} / \mathrm{mL}$, respectively) but a rather weak amount from RP $(20 \mu \mathrm{g} / \mathrm{mL})$. BP that is producing siderophores released more phosphate from RP $(60 \mu \mathrm{g} / \mathrm{mL})$ than from TCP $(24 \mu \mathrm{g} / \mathrm{mL})$. The latter two strains AV and DE1 were weak siderophore producers and yielded weak amount of phosphate from TCP $(18 \mu \mathrm{g} / \mathrm{mL}$ and $7 \mu \mathrm{g} / \mathrm{mL}$, respectively) as well as from $\mathrm{RP}(10 \mu \mathrm{g} / \mathrm{mL}$ and $14 \mu \mathrm{g} / \mathrm{mL}$, respectively).

\subsection{Taxonomical Characterization of the Selected Isolates}

In order to determine whether the 10 isolates were similar or different strains, their ability to assimilate 10 different carbon sources was tested. Most strains were able to use mannitol, lactose, glucose, fructose, maltose, galactose, sucrose, sorbitol and glycerol as sole carbon sources, except AV that did not use mannitol, lactose, maltose, fructose and sorbitol; DE2, BYC, BP, AV and BX that did not use fructose; AYD that did not use maltose (Table 3) and DE2, BP and BX that did not use nor maltose nor fructose (Table 3). This preliminary analysis suggested that these strains were likely to be different.

These 10 isolates were also evaluated for their ability to withstand salt stress by growing at $\mathrm{NaCl}$ concentrations of 5,7 and $10 \mathrm{~g} / \mathrm{L}$. All strains showed the best growth at 5 and $7 \mathrm{~g} / \mathrm{L} \mathrm{NaCl}$ (Table 3) except DE2, AYD and DE1, while CYM and BX showed better growth at $10 \mathrm{~g} / \mathrm{L} \mathrm{NaCl}$ (Table 3). Therefore, these strains could potentially be halotolerant. The analysis of cellular constituents of all isolates revealed the presence of L- diaminopimelic acid (DAP) isomer (Table 3), confirming that they belong to the Streptomyces genera.

The sequences of $16 \mathrm{~S}$ rRNA gene of the 10 strains were analyzed using BLAST ( http:/ / www.ncbi.nlm.nih.gov/BLAST accessed: 29 March 2021) and the LEBIBI [39] and GenBank databases. They were all found to belong to the Streptomyces genus bearing an identity of at least $99 \%$. Nucleotide sequences of partial $16 \mathrm{~S}$ rRNA of the identified isolates were deposited into Gen-Bank Database (http: / / www.ncbi.nlm.nih.gov / GenBank / accessed: 29 March 2021), under the accession numbers listed in Table 4. 
Table 3. Biochemical and morphological characteristics of the 10 selected isolates.

\section{TCP Solubilizing Actinomycete Isolates}

\begin{tabular}{|c|c|c|c|c|c|c|c|c|c|c|}
\hline \multirow{2}{*}{$\begin{array}{l}\text { Origin } \\
\text { Strains }\end{array}$} & \multirow{2}{*}{$\begin{array}{c}\text { Site } 3 \\
\text { DE2 }\end{array}$} & \multicolumn{6}{|c|}{ Site 1} & \multirow{2}{*}{$\begin{array}{c}\text { Site } 3 \\
\text { DE1 }\end{array}$} & \multirow{2}{*}{$\begin{array}{l}\text { Site } 2 \\
\text { CYM }\end{array}$} & \multirow{2}{*}{$\begin{array}{c}\text { Site } 1 \\
\mathrm{BX}\end{array}$} \\
\hline & & BYC & AYD & $\mathrm{AZ}$ & $\mathrm{AI}$ & $\mathrm{BP}$ & AV & & & \\
\hline ISP 3 & +++ & ++ & ++ & ++ & ++ & ++ & ++ & + & + & + \\
\hline ISP4 & +++ & - & - & - & - & - & - & - & - & - \\
\hline ISP6 & + & - & - & - & + & - & - & - & - & + \\
\hline Aerial spore mass & White & White & Gray & Gray & Green & White & White & $\begin{array}{l}\text { Clear } \\
\text { green }\end{array}$ & White & White \\
\hline Soluble pigment & Yellow & - & - & - & - & - & - & Yellow & - & - \\
\hline Colony reverse & Yellow & $\begin{array}{l}\text { Bright } \\
\text { yellow }\end{array}$ & Brown & Yellow & $\begin{array}{l}\text { Clear } \\
\text { Gray }\end{array}$ & Yellow & Brown & Brown & Yellow & Green \\
\hline DAP-isomer & LL & LL & LL & LL & LL & LL & LL & LL & LL & LL \\
\hline \multicolumn{11}{|l|}{ C. source utilization } \\
\hline Mannitol & + & + & + & + & + & + & - & + & + & + \\
\hline Lactose & + & + & + & + & + & + & - & + & + & + \\
\hline Glucose & + & + & + & + & + & + & + & + & + & + \\
\hline Maltose & - & + & - & + & + & - & - & + & + & - \\
\hline Galactose & + & + & + & + & + & + & + & + & + & + \\
\hline Glycerol & + & + & + & + & + & + & + & + & + & + \\
\hline Sucrose & + & + & + & + & + & + & + & + & + & + \\
\hline Citrate & + & + & + & + & + & + & - & - & + & - \\
\hline Fructose & - & - & + & + & + & - & - & + & + & - \\
\hline Sorbitol & + & + & + & + & + & + & - & + & + & + \\
\hline
\end{tabular}

Growth at different

concentration of $\mathrm{NaCl}$

$(\mathrm{g} / \mathrm{L})$

\begin{tabular}{|c|c|c|c|c|c|c|c|c|c|c|}
\hline $5(\mathrm{~g} / \mathrm{L})$ & ++ & +++ & + & +++ & ++ & +++ & ++ & +++ & +++ & +++ \\
\hline $7(\mathrm{~g} / \mathrm{L})$ & + & ++ & +++ & +++ & +++ & +++ & +++ & +++ & +++ & +++ \\
\hline $10(\mathrm{~g} / \mathrm{L})$ & ++ & ++ & + & ++ & ++ & + & - & +++ & +++ & +++ \\
\hline
\end{tabular}

+: Tested positive/utilized as substrate; -: tested negative/not utilized as substrate; +++: Strong growth/production; ++: Medium growth/production; +: Low growth/production.

Table 4. 16S rRNA identification of the 10 selected isolates.

\begin{tabular}{ccc}
\hline Strains & 16S rRNA Identification & Accession Number \\
\hline AYD & Streptomyces bellus & MW797036 \\
DE2 & Streptomyces saprophyticus & MW797316 \\
BYC & Streptomyces enissocaesilis & MW795692 \\
AI & Streptomyces tunisiensis & MW797002 \\
AZ & Streptomyces bellus & MW797031 \\
BP & Streptomyces coerulescens & MW797037 \\
AV & Streptomyces bellus & MW797030 \\
CYM & Streptomyces cyaneofuscatus & MW797121 \\
BX & Streptomyces bellus & MW797038 \\
DE1 & Streptomyces bellus & MW802700 \\
\hline
\end{tabular}


$16 \mathrm{~S}$ rDNA sequences of Streptomyces species retrieved from Genbank as well as that of our strains were used for the construction of a phylogenic tree (Figure 5). Six strains (BP, BX, DE1, AV, AYD and AZ) were closely related to Streptomyces bellus, AI was related to $S$. tunisiensis, BYC to S. enissocaesilis, DE2 to S. saprophyticus and CYM to S. cyaneofuscatus.

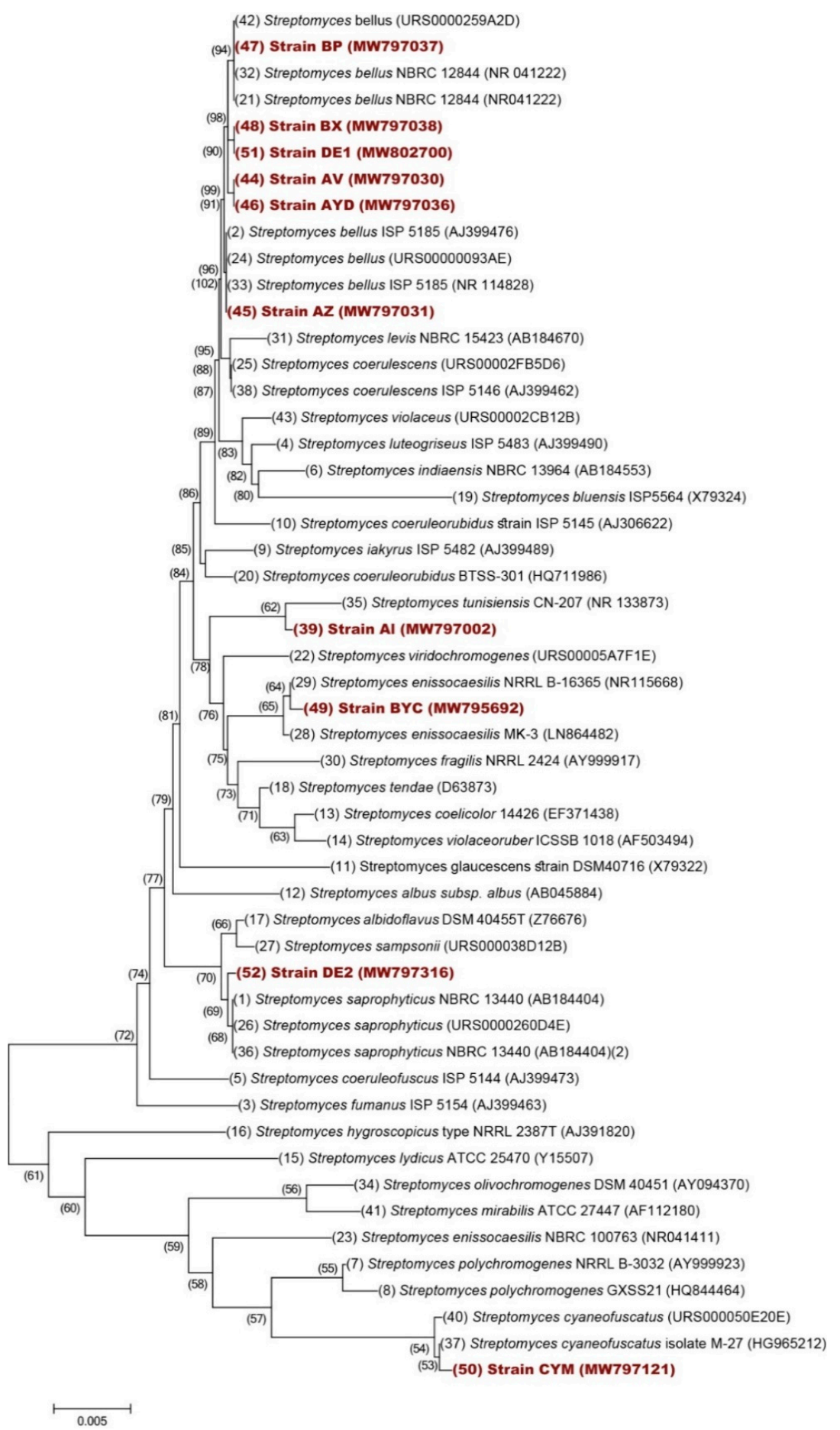

Figure 5. Neighbor-Joining phylogenetic tree of the 10 isolated strains and 42 Streptomyces species based on nearly complete $16 \mathrm{~S}$ rRNA gene sequences (1400 nt). Numbers at nodes indicate levels of bootstrap support (\%) based on a Neighbor-Joining analysis of 1000 resampled datasets; only values $>50 \%$ are given. Accession numbers are given in parentheses. Bar, 0.005 nucleotide substitutions per site. 


\section{Discussion}

Most publications describing isolation of phosphate-solubilizing bacteria (PSB) used growth on TCP, rather than on RP, but analysis of scientific literature concerning biological $P$ solubilization suggested that this substrate might not be the most appropriate to screen for PSB able to enhance plant growth $[45,46]$. In consequence, we instead used growth on RP as first screen to isolate PSM and our strategy and outcomes are summarized in Figure 6.

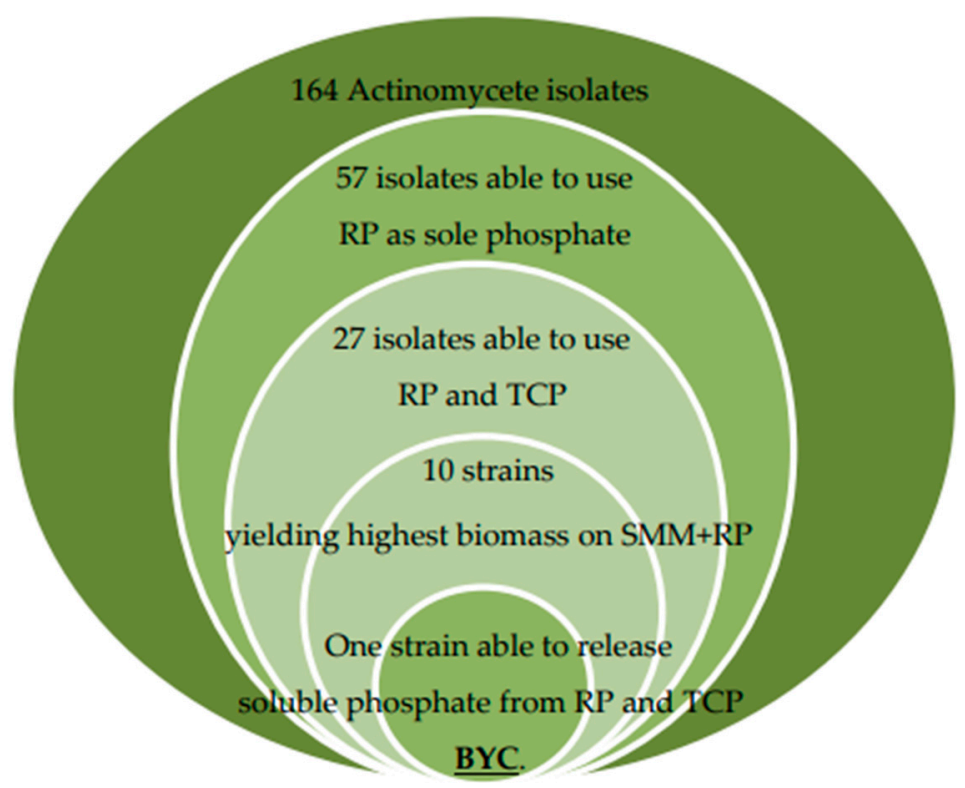

Figure 6. Schematic representation of the experimental strategy used to isolate efficient TCP/RP solubilizing Actinomycete strains.

Our study revealed that $28 \%$ of the Actiomycetes isolated from sugar beet soils had the ability to grow on RP as sole phosphate source and among them only $47.36 \%$ had also the ability to grow on TCP as sole phosphate source. This difference is difficult to explain but suggested that the TCP and RP solubilizing processes may involve different mechanisms or that the greatest diversity of mineral elements present in RP compared to $\mathrm{TCP}$, is necessary for the growth of some strains.

Five strains (DE2, BYC, AYD, AZ and AI) among the ten strains studied were able to release significant amount of phosphorus from TCP $(>60 \mu \mathrm{g} / \mathrm{mL})$. Their solubilization activity was comparable to that of Azospirillum sp., Pantoea agglomerans and Pseudomonas fluorescens, from wheat rhizosphere in Jensen medium [47]; however, it was much higher than that reported for a Streptomyces sp. (AH6 strain) isolated from the rhizospheric soil of Calluna vulgaris L $[20,48]$.

However, among these five efficient solubilizing strains, only one strain, BYC related to Streptomyces enissocaesilis (Figure 5), was able to release similar amount of phosphorus from $\mathrm{RP}$ and TCP and another strain, $\mathrm{BP}$, was able to release even more phosphate from RP than from TCP. These two strains are thus of special interest and the mass spec analysis of the molecules present in their supernatant is expected to lead to the purification and structural characterization of potentially novel siderophores and/or organic acids contributing to their efficient RP solubilization process.

In $\mathrm{RP}$ the $\mathrm{pH}$ of the medium of all strains, except that of $\mathrm{BYC}$, was between 7 and 8 , suggesting that the solubilization process does not involve the excretion of organic acids but rather that of siderophores $[41,49]$. The very efficient solubilization process of BYC might involve both the acidification of the growth medium and the excretion of siderophores.

In TCP, the growth medium of DE2 and AZ turned out to be acidic but that of the other strains was close to or above 7. This suggested that the TCP solubilization process of 
DE2 and AZ might involve the excretion of organic acids. To our knowledge, that is the first report of Actinomycete strains solubilizing insoluble $\mathrm{P}$ via the production of organic acids. In this process, negatively charged organic acids are thought to chelate $\mathrm{Ca}^{2+}$ counter ions of phosphate $[43,47]$. A similar process was reported in other fungi such Penicillium aurantiogriseum [50] and Penicillium radicum [41,47,49,51].

In conclusion, we anticipate that our most efficient RP solubilizing strain, BYC, produced in large scale may constitute a novel kind of fertilizers useful to solubilize the phosphate trapped in the soil to feed and stimulate sugar beet growth. Such strategy would contribute to the development of a bio-based economy supporting a sustainable and environmentally friendly agriculture.

Author Contributions: Conceptualization, H.H. and Y.A.; methodology, Y.A. and H.H.; software, Y.A., A.S. and S.L.; Validation H.H., S.L., D.D. and M.J.V.; formal analysis, H.H., S.L., A.S., F.K. and M.J.V.; investigation, Y.A. and H.H.; resources, H.H., A.H., S.L., S.E.K. and D.D.; data curation, Y.A., H.H., T.E.R., S.L. and M.J.V.; writing-original draft preparation, Y.A. and H.H.; writing-review and editing, H.H., M.J.V., D.D., S.L., A.S., A.H., N.S., T.E.R. and F.K.; visualization, H.H.; supervision, H.H.; project administration, H.H. and A.H. All authors have read and agreed to the published version of the manuscript.

Funding: This research received no external funding.

Institutional Review Board Statement: Not applicable.

Informed Consent Statement: Not applicable.

Data Availability Statement: The data that support the findings of this study are available from the corresponding author upon reasonable request.

Acknowledgments: The authors would like to express their appreciation and gratitude to Jamal Koubali, Department of English, Beni Mellal, Sultane Moulay Slimane University, Morocco for his careful revision of the language of this manuscript. Also, authors are grateful for Laila Hamroud from the Laboratory of Zoology, University of Mons, Belgium for her help with soil samplings from the Beni-Mellal region.

Conflicts of Interest: The authors declare no conflict of interest.

\section{References}

1. Krishnaraj, P.U.; Dahale, S. Mineral phosphate solubilization: Concepts and prospects in sustainable agriculture. Proc. Indian Natl. Sci. Acad. 2014, 80, 389-405. [CrossRef]

2. Secco, D.; Bouain, N.; Rouached, A.; Prom-u-thai, C.; Hanin, M.; Pandey, A.K.; Rouached, H. Phosphate, phytate and phytases in plants: From fundamental knowledge gained in Arabidopsis to potential biotechnological applications in wheat. Crit. Rev. Biotechnol. 2017, 1-13. [CrossRef]

3. Ha, S.; Tran, L. Understanding plant responses to phosphorus starvation for improvement of plant tolerance to phosphorus deficiency by biotechnological approaches. Crit. Rev. Biotechnol. 2014, 34, 16-30. [CrossRef] [PubMed]

4. Zou, X.; Binkley, D.; Doxtader, K.G. A new method for estimating gross phosphorus mineralization and immobilization rates in soils. Plant Soil 1992, 147, 243-250. [CrossRef]

5. Zhu, J.; Li, M.; Whelan, M. Phosphorus activators contribute to legacy phosphorus availability in agricultural soils: A review. Sci. Total Environ. 2018, 612, 522-537. [CrossRef]

6. Chabot, R.; Antoun, H.; Cescas, M.P. Growth promotion of maize and lettuce by phosphate-solubilizing Rhizobium leguminosarum biovar, phaseoli. Plant Soil 1996, 311-321. [CrossRef]

7. Kishore, N.; Pindi, P.K.; Reddy, S.R. Plant biology and biotechnology: Plant diversity, organization, function and improvement. In Plant Biology and Biotechnology; Springer: Berlin/Heidelberg, Germany, 2015; Volume 1, pp. 1-827; ISBN 9788132222866.

8. Tirado, R.; Allsopp, M. Phosphorus in agriculture Problems and solutions. Greenpeace Int. 2012, 35, 3-30.

9. Mishra, K.B.; Kumar, K.; Dubey, P.N.; Aishwath, O.P.; Kant, K.; Sorty, A.M.; Bitla, U. Influence on yield and quality of fennel (Foeniculum vulgare Mill.) grown under semi-arid saline soil, due to application of native phosphate solubilizing rhizobacterial isolates. Ecol. Eng. 2016, 97, 327-333. [CrossRef]

10. Ben Farhat, M.; Boukhris, I.; Chouayekh, H. Mineral phosphate solubilization by Streptomyces sp. CTM396 involves the excretion of gluconic acid and is stimulated by humic acids. FEMS Microbiol. Lett. 2015, 362, 1-8. [CrossRef]

11. Bargaz, A.; Lyamlouli, K.; Chtouki, M.; Zeroual, Y.; Dhiba, D. Soil microbial resources for improving fertilizers efficiency in an integrated plant nutrient management system. Front. Microbiol. 2018, 9, 1-25. [CrossRef] 
12. De Boer, M.A.; Wolzak, L.; Slootweg, J.C. Phosphorus, Reserves, Production and Applications; Springer: Berlin/Heidelberg, Germany, 2019; ISBN 9789811080319. [CrossRef]

13. Vassilev, N.; Vassileva, M.; Fenice, M.; Federici, F. Immobilized cell technology applied in solubilization of insoluble inorganic (rock) phosphates and P plant acquisition. Bioresour. Technol. 2001, 79, 263-271. [CrossRef]

14. Karimi, E.; Safaie, N.; Shams-Baksh, M.; Mahmoudi, B. Bacillus amyloliquefaciens SB14 from rhizosphere alleviates Rhizoctonia damping-off disease on sugar beet. Microbiol. Res. 2016, 192, 221-230. [CrossRef]

15. Hamdali, H.; Bouizgarne, B.; Hafidi, M.; Lebrihi, A.; Virolle, M.J.; Ouhdouch, Y. Screening for rock phosphate solubilizing Actinomycetes from Moroccan phosphate mines. Appl. Soil Ecol. 2008, 38, 12-19. [CrossRef]

16. Verma, P.J.; Yadav, J.; Tiwari, N.K.; Jaiswal, K.D. Evaluation of plant growth promoting activities of microbial strains and their effect on growth and yield of chickpea (Cicer arietinum L.) in India. Soil Biol. Biochem. 2014, 70, 33-37. [CrossRef]

17. Walpola, B.C.; Yoon, M. Isolation and characterization of phosphate solubilizing bacteria and their co-inoculation efficiency on tomato plant growth and phosphorous uptake. Afr. J. Microbiol. Res. 2013, 7, 266-275. [CrossRef]

18. Redani, L. Competitivite, Valorisation Des ressources et Objectifs de Securité Alimentaire pour la Filier Sucrière au Maroc. Ph.D. Thesis, Gembloux Agro-Bio Tech Université de Liège, Gembloux, Belgium, 2015. Corpus ID: 161085096.

19. Hamdali, H.; Hafidi, M.; Virolle, M.J.; Ouhdouch, Y. Growth promotion and protection against damping-off of wheat by two rock phosphate solubilizing actinomycetes in a P-deficient soil under greenhouse conditions. Appl. Soil Ecol. 2008, 40, 510-517. [CrossRef]

20. Hamim, A.; Boukeskasse, A.; Ouhdouch, Y.; Farrouki, A.; Barrijal, S.; Lucie, M.; Mrabet, R.; Duponnois, R.; Hafidi, M. Phosphate solubilizing and PGR activities of ericaceous shrubs microorganisms isolated from Mediterranean forest soil. Biocatal. Agric. Biotechnol. 2019, 19, 1-8. [CrossRef]

21. Saravanakumar, K.; Arasu, V.S.; Kathiresan, K. Effect of Trichoderma on soil phosphate solubilization and growth improvement of Avicennia marina. Aquat. Bot. 2013, 104, 101-105. [CrossRef]

22. Soumare, A.; Boubekri, K.; Lyamlouli, K.; Hafidi, M.; Ouhdouch, Y.; Kouisni, L. From isolation of phosphate solubilizing microbes to their formulation and use as biofertilizers: Status and needs. Front. Bioeng. Biotechnol. 2020, 7, 1-14. [CrossRef]

23. Majeed, A.; Kaleem Abbasi, M.; Hameed, S.; Imran, A.; Rahim, N. Isolation and characterization of plant growth-promoting rhizobacteria from wheat rhizosphere and their effect on plant growth promotion. Front. Microbiol. 2015, 6, 1-11. [CrossRef] [PubMed]

24. Barka, E.A.; Vatsa, P.; Sanchez, L.; Gaveau-Vaillant, N.; Jacquard, C.; Meier-Kolthoff, J.P.; Klenk, H.-P.; Clément, C.; Ouhdouch, Y.; van Wezel, G.P. Correction for Barka et al., Taxonomy, Physiology, and Natural Products of Actinobacteria. Microbiol. Mol. Biol. Rev. 2016, 80, 1-43. [CrossRef] [PubMed]

25. Elbehri, A.; Felloun, H.; Nbou, M.; Yamini, B.; Balaghi, R.; Hammani, A.; Mzouri, E.H.; Moussadek, R.; Elhaired, T.; Rouchdi, M.; et al. Actes de l'Atelier de travail: "Projet pilote d'appui aux petits producteurs pour une meilleure adaptation aux changements climatiques dans la région du Tadla Azilal»; Centre national de documentation; FAO: Béni Mellal, Morocco, 2011.

26. El Hammoumi, N.; Sinan, M.; Lekhlif, B.; Lakhdar, M. Use of multivariate statistical and geographic information system (GIS)basedapproach to evaluate ground water quality in the irrigated plainof Tadla (Morocco). Int. J. W. Res. Environ. 2013, 5, 77-93. [CrossRef]

27. Barakat, A.; El Baghdadi, M.; Rais, J.; Nadem, S. Assessment of Heavy Metal in Surface Sediments of Day River at Beni-Mellal Region, Morocco. Res. J. Environ. Earth Sci. 2012, 4, 797-806.

28. El Baghdadi, M.; Barakat, A.; Mohamed, S.; Nadem, S. Heavy metal pollution and soil magnetic susceptibility in urban soil of Beni Mellal City (Morocco). Environ. Earth Sci. 2011, 1-15. [CrossRef]

29. Carter, M.R.; Gregorich, E.G. Physical and Chemical Methods of Soil and Water Analysis, 2nd ed.; Canadian Society of Soil Science, Taylor \& Francis: Abingdon, UK, 2006.

30. Hakkou, R.; Benzaazoua, M.; Bussière, B. Valorization of phosphate waste rocks and sludge from the Moroccan phosphate mines: Challenges and perspectives. Procedia Eng. 2016, 138, 110-118. [CrossRef]

31. Quin, P.; Joseph, S.; Husson, O.; Donne, S.; Mitchell, D.; Munroe, P.; Phelan, D.; Cowie, A.; van Zwieten, L. Lowering $\mathrm{N}_{2} \mathrm{O}$ emissions from soils using eucalypt biochar: The importance of redox reactions. Sci. Rep. 2015, 5, 1-14. [CrossRef]

32. Shirling, E.B.; Gottlieb, D. Methods for characterization of Streptomyces species. Int. J. Syst. Bacteriol. 1966, 16, 313-340. [CrossRef]

33. Olsen, S.R.; Sommers, L.E. Methods of Soil Analysis, Part 2; American Society of Agronomy: Madison, WI, USA, 1982; pp. 403-430.

34. Schwyn, B.; Neilands, J.B. Universal chemical assay for the detection and determination of siderophores. Anal. Biochem. 1987, 160, 47-56. [CrossRef]

35. Louden, B.C.; Haarmann, D.; Lynne, A.M. Use of blue agar CAS assay for siderophore detection. J. Microbiol. Biol. Educ. 2011, 12, 51-53. [CrossRef]

36. Nonomura, H. Key for classification and identification of 485 species of the Streptomyces included in the ISP. J. Ferment. Technol. 1974, 52, 78-92.

37. Becker, B.; Lechevalier, M.P.; Gordon, R.E.; Lechevalier, H.A. Rapid differentiation between Nocardia and Streptomyces by paper chromatography of whole-cell hydrolysates. Appl. Microbiol. 1964, 12, 421-423. [CrossRef]

38. Hopwood, A.D.; Bibb, J.M.; Chater, F.K.; Kjeser, T.; Bruton, C.J.; Kieser, H.M.; Lydiate, J.D.; Smith, P.C.; Werd, J.M.; Schrempf, H. Genetic Manipulation of Streptomyces: A Laboratory Manual; The John Innes Foundation: Norwich, UK, 1986. [CrossRef] 
39. Flandrois, J.P.; Perrière, G.; Gouy, M. le BIBIQBPP: A set of databases and a webtool for automatic phylogenetic analysis of prokaryotic sequences. BMC Bioinform. 2015, 16, 1-12. [CrossRef] [PubMed]

40. Saitou, N.; Nei, M. The Neighbor-joining method: A new method for reconstructing phylogenetic trees. Mol. Biol. Evol. 1987, 4, 406-425. [CrossRef] [PubMed]

41. Felsenstein, J. Phylogenies and the comparative method. Am. Nat. 1985, 125, 1-15. [CrossRef]

42. Kimura, M. A simple method for estimating evolutionary rates of base substitutions through comparative studies of nucleotide sequences. J. Mol. Evol. 1980, 16, 111-120. [CrossRef]

43. Kumar, S.; Stecher, G.; Li, M.; Knyaz, C.; Tamura, K. MEGA X: Molecular evolutionary genetics analysis across computing platforms. Mol. Biol. Evol. 2018, 35, 1547-1549. [CrossRef]

44. Ahemad, M.; Kibret, M. Mechanisms and applications of plant growth promoting rhizobacteria: Current perspective. J. KING SAUD Univ. Sci. 2013, 1-20. [CrossRef]

45. Mahamuni, S.V.; Wani, P.V.; Patil, A.S. Isolation of phosphate solubilizing fungi from rhizosphere of sugarcane \& sugar beet using TCP \& RP solubilization. Asian J. Biochem. Pharm. Res. 2012, 2, 237-244.

46. Nath, D.; Maurya, B.R.; Meena, V.S. Documentation of five potassium- and phosphorus-solubilizing bacteria for their K and P-solubilization ability from various minerals. Biocatal. Agric. Biotechnol. 2017, 10, 174-181. [CrossRef]

47. Narula, N.; Kumar, V.; Behl, R.K.; Deubel, A.; Gransee, A.; Merbach, W.; Science, S.; Nutrition, P. Effect of P-solubilizing Azotobacter chroococcum on N, P, K uptake in P-responsive wheat genotypes grown under greenhouse conditions. J. Plant Nutr. Soil Sci. 2000, 163, 393-398. [CrossRef]

48. Pikovskaya, R.I. Mobilization of phosphorus in soil connection with the vital activity of some microbial species. Microbiology 1948, 17, 362-370.

49. Panda, P.; Somsubhra, C.; Ray, D.P.; Mahato, B.; Pramanik, B.; Choudhury, A. Solubilization of tricalcium phosphate and production of IAA by phosphate solubilizing bacteria isolated from tea rhizosphere soil. Econ. Aff. 2015, 60, 805-809. [CrossRef]

50. Illmer, P.; Schinner, F. Solubilization of inogranic phosphates by microorganisms isolated from forest soils. Soil Biol. Biochem. 1992, 24, 389-395. [CrossRef]

51. Whitelaw, M.A.; Harden, T.J.; Helyar, K.R. Phosphate solubilisation in solution culture by the soil fungus Penicillium radicum. Soil Biol. Biochem. 1999, 31, 655-665. [CrossRef] 